\title{
STATUTES RELATING TO TELEPHONE COMPANIES.
}

\author{
(Continued.)
}

Minnesota repealed the Act of 1881 (Gen. Laws, extra session, chap. 68 ; note to p. 215 , vol. 2, Gen. Stat. 1889) by an Act, approved March 3, 1887 (chap. 138, Gen. Laws, p. 225 ; Gen. Stat. vol. 2, p. 217), providing-

SBcriox 1. Each and every telephone company, corporation, or association, partnership or person, owning or operating, or which shall hereafter own or operate, within this State, for hire or compensation, any telephone or telephone line or lines, the rate and manner of the taxation of which for any purpose, has not been fixed or prescribed by special charter granting snch-franchise, shall on or before the first day of February, one thonsand eight hundred and eighty-eight, and annually thereafter, on or before the first day of February in each year pay into the treasury of this State two per centum of the gross earnings of said company, corporation, association, partnership, or person, earned upon the business done wholly in the State, during the year ending upon the first day of July, immediately preseding the day upon which payment shall be made as aforesaid, which payment shall be made in lieu of, and in full payment of, all taxes and assessments of every description, levied upon or payable by said company, corporation, association, partnership, or person, by virtue of any law of this State, upon all personal property, rights, privileges, immunities, or franchises, owned and used by said company, corporation, association, partnership, or person, in the operation and management of its, their, or his business, within this State: Provided, however, that any and all sums of money which may be paid ont by such company, corporation, association, partnership, or person, as rojalties, upon patented articles used in said business, shall be deducted from the gross receipts, and the two per centum shall be levied only apon the balance of such gross receipts, after the said amount so paid as royalty shall have been deducted.

Section 2. For the purpose of ascertaining the gross earnings aforesaid, each and every such telephone company, corporation, association, partnership, or person, doing business in this State as aforesaid, shall, on or before the first day of September, in the year of our Lord one thousand eight hundred and eighty-seven, and annnally thereafter, on or before the first day of September of each and every year, make and transmit to the State Auditor of the State of Minnesota, in his office at the Capitol at St. Paul, a full and trne report and statement under oath of the proper officers of said company, corporation, association, partnership, or of said person, of their said business as it existed on the first day of July, immediately preceding the making of such report, specifying :-

First. The gross receipts on all basiness done wholly within this State, during the year ending immediately preceding said first day of July. 
Second. All sums of money paid out during said year, as royalties, upon all patented articles or instruments used by said company, corporation, association, partnership, or person.

Sectios 3. The property, books, records (accounts), papers, and proceedings, so far as they relate to the condition, operation, or management of said telephone companies, corporations, associations, partnerships, or persons, shall, at all times during business hours, be subject to the examination and inspection of the said State Auditor, and he shall have power to examine, under oath or affirmation, each and all directors, officers, managers, agents, and employés, of any such telephone company, corporation, association, partnership, or other persons, concerning any matter relating to the subject of such report.

Secrios 4. Every telephone company, association, corporation, partnership, or person, or any of their, its, or his officers or managing agents, who shall wilfully neglect or refuse to make, or furnish, any report required in this Act, at the time herein required, or who shall wilfully or unlawfully hinder, delay or obstruct said State Auditor in the discharge of his duties hereby imposed upon him, shall forfeit and pay a sum of not less than tro hundred dollars, nor more than five hundred dollars, for snch offence, to be reccvered in a civil action upon complaint of said State Auditor, and in his name, for the use and benetit of the State of Minnesota; and every such telephone company, corporation, association, partwership, or person, and every officer, and managing agent thereof, whose duty it may be to make such report, shall be liable to a like penalty for every period of ten days it, he, or they shall wilfully neglect or refuse to make such report, and any person who shall, in any affidavit, report, statement, or examination, provided for or required in this Act, intentionally or knowingly swear falsely to any matter to which the same, or either of them, relate, shall be deemed to have committed the crime of perjury, and be punished accordingly.

Sectros 5. The State Anditor shall on or before the first day of January of each year immediately following the filing of such report or statement hereinbefore mentioned, make and file with the State Treasurer, a report shoring the amonnt of taxes as payment due and payable from each and every such company, association, corporation, partnership, or person owning or operating any telephone or telephone lines within this State.

Sectios 6. For the purpose of securing to the State the payment of the aforesaid taxes or sums, the State shall have a Jien upon each and all of the telephone lines and instruments for or on account of the operation of which such tax, sum, or per centum shall become payable, which said liens hereby created shall have and take precedence of any or all other liens, demands, decrees, and judgments upon or against said property, or against the party by Thich said tax, sum, or per centum shall be payable, and which lien hereby created may be enforced by the sale of any such property to which said lien may attach, by the State Treasurer, in the manner preseribed by section one hundred and thirty-one of chapter eleven of the General Statutes of eighteen hundred and seventy-eight, relating to telegraphs, and telegraph companies, or by other process of law.

\section{Missodri provides at length, for the formation and regula-}




\section{tion of telephone companies (Rev. Stat. 1879, chap. 21, art.} V., page 157)-

Sxc. 874. Any number of persons, not less than five, being subscribers to the stook of any contemplated telephone or magnetic telegraph company, may be formed into a corporation, for the purpose of constructing, owning, operating, and maintaining lines of telephone or magnetic telegraph, apon complying Fith the following requirements : Whenever stock, to the amount of not less than twenty thonsand dollars, shall have been subscribed, for the purpose of forming a telegraph company, or five hundred dollars for the purpose of forming a telephone company, the subscribers to such stock shall elect from among themselves such number of directors, not less than three nor more than thirteen, as they may determine, and shall severally subscribe articles of association, which shall set forth the name of the corporation, the amount of capital stock of the company, the number of directors, the amount of each share of stock, the number and names of the subscribers to the stock of the company, and the number of shares of stock taken by each subscriber, the location of the principal office or place of basiness of the company, and the names of its authorized agents thereat, which shall be verified by the affidavit of at least three of the subscribers thereto, and shall pay into the State treasury, fifty dollars for the first fifty thousand dollars, or less of its capital stock, and the further sum of five dollars for every additional ten thousand dollars thereof (as amended by Act of April 2, 1885, Laws, page 95).

SEc. 875. The articles of association shall be filed in the office of the Secretary of State, who shall record and carefully preserve the same in his office, and thereapon the subscribers, and the persons who from time to time, shall become stockholders in such company, and their successors, shall be a body politic and corporate, by the name stated in such articles of association, and shall have power to construct, own, operate, and maintain lines of telephone and magnetic telegraph, between such points as they may, from time to time, determine, and to make such reasonable charges for the use of the same as they may establish; and shall have power to lease or attach to their lines, other telephone or telegraph lines, by lease or purchase; and meetings of the stockholders or of the directors of such corporation may be held for the transaction of business, as well withouts as within this State. A copy of the articles of association, certified by the Secretary of State, or his deputy, under the seal of the State, shall be prima facie evidence of the incorporation of such company, and of the facts stated therein. Any such company, though its board of directors, with the consent of the persons holding the larger amount in value of the stock, shall have power to reduce its capital to any amount not below the actual cost of construction, and in like manner and with like consent, to increase the capital stock from time to time, as in their judgment may be necessary, not exceeding an amount, which, when fully paid up, shall be required for the business of the company, which consent shall be obtained in the manner preseribed by law.

Sec. 876. There shall be an annual election of directors, to serve for the ensuing year, notice of which, appointing the time and place, shall be given by the directors chosen, as provided by law, for the first annual election, and 
thereafter by their successors in office; which notice shall be published, not less than twenty days previous thereto, in a newspaper published in the county, where the principal office of the company shall be situated. The directors shall hold their offices for one year, and until their successors are duly elected and qualified. They shall elect one of their number to be President of the company, and may appoint such other officers and agents as [may] be prescribed by the articles of association or by-laws of the company.

Sec. 877. No person shall be chosen a director who is not a stockholder, owning stock absolutely in his own right and qualified to rote at the election at which he is chosen, and all elections for directors shall conform to the requirements of lsw, governing private corporations.

SEc. 878. The board of directors may at any time, meet for the transaction of business, upon a call of the President of the company.

Szc. 879. Companies organized under the provisions of this article, for the purpose of constructing and maintaining telephone or magnetic telegraph lines, are authorized to set their poles, piers, abutments, wires and other fixtures, along, and across any of the public roads, streets and waters of this State, in such manner as not to incommode the public, in the use of such roads, streets and waters.

Sec. 880. Such companies are also authorized to enter upon any land, whether owned by private persons, in fee, or in any less estate, or by any corporation, whether acquired by purchase or by virtue of any provision in the charter of such corporation, for the purpose of making preliminary surveys and examinations with a view to the erection of any telephone or telegraph lines, and, from time to time, to appropriate so much of said lands as may be necessary, to erect such poles, piers, abutments, wires and other necessary fixtures for a telephone or magnetic telegraph, and to make such changes of location of any part of said lines, as may, from time to time, be deemed necessary, and shall have a right of access to construct said line, and, when erected, from time to time, as may be required, to repair the same; and may proceed to obtain the right of way, and to condemn said lands in the manner provided by law.

SEc.. 881. No company shall have power to contract with any owner of land, for the right to erect or maintain a telephone or telegraph line over his lands, to the exclusion of the lines of other companies organized under the provisions of this article.

Sec. 882. Any company, incorporated as herein provided, may contract, own, use, and maintain any line or lines of telephone or magnetic telegraph, whether wholly within or wholly, or partly, beyond the limits of this State, and shall have power to lease or attach to the line or lines of such company, other telephone or telegraph lines, by lease or purchase, and may join with any other corporation or association in constructing, leasing, owning, using or maintaining their line or lines, upon such terms as may be agreed upon between the directors or managers of the respective corporations, and may own and hold any interest in such line or lines, or become lessees thereof, on such terms as the respective corporations may agree.

SEc. 883. It shall be the duty of every telephone or telegraph company, 
jnoorporated or unincorporated, operating any telephone or telegraphic line in this State, to receive dispatches from and for other telephone or telegraph lines, and from or for any individual, and upon payment or tender of their usual oharges for transmitting dispatches, as established by the rules and regulations of such telephone or telegraph line, to transmit the same with impartiality and good faith, under a penalty of one hundred dollars for every neglect or refusal so to do, to be recovered, with costs of suit, by civil action, for the benefit of the person or persons or company sending or desiring to send such dispatch.

Sec. 884. Where the person sending the dispatch desires to have it forwarded over the lines of other telephone or telegraph companies, whose termini are respectively within the limits of the usual delivery of such companies, to the place of final destination, and shall tender to the first company the amount of the usual charges for the dispatch to the place of final delivery, it shall be the duty of the company to receive the same, and, without delaying the dispatch, to pay to the succeeding line the necessary charges for the remaining distance, and it shall be the duty of the succeeding line or lines to accept the same, and forward the dispatch in the same manner as if the person sending the same had applied to the agent or operator of such line or lines in person, and paid to him the usual charges; and for omitting so to do, the company or companies orning or operating such line or lines shall severally be liable to the penalty prescribed in section eight hundred and eighty-three.

Src. 885. In all cases where application is made to any telephone or telegraph company, or the operator, agent, clerk or servant thereof, to send a dispatch, it shall be the duty of such operator, agent, clerk or servant who may receive dispatches at that station, plainly to inform the applicant, and if required by him, to write upon the dispatch, that the line is not in working order, or that the dispatches already on hand for transmission will occupy the time, so that the dispatch offered cannot be transmitted within the time required, if the facts be so; and for omitting so to do, or for intentionally giving false information to the applicant, in relation to the time within which the dispatch offered may be sent, such operator, agent, clerk or servant, and the company by whioh he is employed, shall incur a like penalty as in section eight hundred and eighty-three.

SBc. 886. If any officer, manager, agent or operator of any telephone or telegraph line, operating in this Stat 6 , or any other person, shall knowingly transmit by such telephone or telegraph line, any false communication or intelligence, with intent to injure any one, or to speculate in any article of merchandise, commerce or trade, or with intent that another may do so, or shall knowingly send or deliver any dispatch that is forged or not authorized by the person whose name purports to be signed thereto, shall, on conviction thereof, in the Court having criminal jurisdiction in the proper county, be liable to the same penalty as is provided in section eight hundred and eighty-three.

Szc. 887. Every telephone or telegraph company now organized, or which may hereafter be organized, under the laws of this State shall be liable for special damages occasioned by the failure or negligence of their operators or servants, in receiving, copying, transmitting or delivering dispatches; and for 
the disclosure of any of the contents of any private dispatches to any person other than to him to whom it was addressed, or to his agent, they shall be liable to the sender of the dispatch and to the person to whom it was addressed, in the sum of fifty dollars to each, recoverable by an action before a justice of the peace, and for all special damages in addition thereto.

SEc. 888. The mayor and aldermen, or board of common council of any city, and the trustees of any incorporated town through which the lines of any teleplione or telegraph company are to pass, may, by ordinance or otherwise, specify where the posts, piers, or abutments shall be located, the kind of posts that shall be used, the height at which the wires shall be run; and such company shall be governed by the regulations thus prescribed; and after the erection of said telephone or telegraph lines, the said mayor and aldermen, or board of common council, and the trustees of any incorporated town, shall have power to direct any alteration in the location or erection of said posts, piers, or abutments, and also in the height at which the wires shall run, having first given such company or its agents opportunity to be heard in regard to such alteration.

SEc. 889. Any person who shall unlawfully and intentionally injure, molest or destroy any of the lines, posts, piers, abutments, or other material, or property, pertaining to any line of telephone or magnetic telegraph, erected in this State, sliall be deemed guilty of a misdemeanor, and shall, upon conviction, be punished by a fine not exceeding five hundred dollars, or by imprisonment in the county jail not exceeding one year, or by both such fine and imprisonment, at the discretion of the Court having cognizance thereof.

SEc. 890. Any telegraph company now organized, or which may hereafter be organized under the laws of this State, may at any regular meeting of the stockholders thereof, by vote of persons holding a majority of the shares of the stock of such company, unite or consolidate with any other company or companies now organized, or which may hereafter be organized, under the laws of the United States, or of any State or Territory, by consent of the company with which it may consolidate or unite, and such consolidated company so formed, may hold, use and enjoy all the rights and privileges conferred by the laws of Missouri on companies separately organized under the provisions of this article, and be subject to the same liabilities.

SEC. 891. All corporations formed under this article shall possess all the powers and privileges granted to corporations by article one of this chapter, relating to the general powers of private corporations, and be subject to all the provisions thereof except as herein otherwise provided.

JOHN B. UHLE.

(To be continued.) 